\title{
Triggers of Farmer-Herder Conflicts in Ghana: A Non-Parametric Analysis of Stakeholders' Perspectives
}

\author{
Stanley K. Dary ${ }^{1}$, Harvey S. James ${ }^{1} \&$ Asaah S. Mohammed ${ }^{2}$ \\ ${ }^{1}$ Department of Agricultural and Applied Economics, University of Missouri, Columbia, USA \\ ${ }^{2}$ Institute of Statistical, Social and Economic Research, University of Ghana, Legon, Ghana \\ Correspondence: Stanley K. Dary, Department of Agricultural and Applied Economics, University of Missouri, \\ 323 Mumford Hall, Columbia, MO 65211, USA. E-mail: skdd45@mail.missouri.edu
}

Received: March 6, 2017 Accepted: March 28, 2017 Online Published: April 19, 2017

doi:10.5539/sar.v6n2p141 URL: https://doi.org/10.5539/sar.v6n2p141

\begin{abstract}
In Ghana, farmer-herder conflicts have become widespread and increasingly assume a violent dimension. Competition over access to and use of land and water resources is at the center of the conflicts. However, competition does not automatically result in conflicts. The conflicts are driven by triggering activities of both farmers and herders. This study identifies triggers of farmer-herder conflicts in the Upper West Region of Ghana and tests the level of agreement among key stakeholder groups on the triggers of these conflicts. This is an important step in determining approaches to farmer-herder conflicts prevention and resolution. The data were collected via focus group discussions of five key stakeholder groups: chiefs-traditional rulers, Fulani herdsmen-cattle owners, crop farmers, civic society-media, and government agencies. Fourteen triggers of conflicts were identified by stakeholders, with destruction of crops by cattle ranking as the most important trigger. In testing agreement among stakeholder groups on triggers of conflicts, only crop farmers, chiefs-traditional rulers and government agencies significantly agree on the triggers of conflicts. There is also moderate level of concordance when the ranking of triggers of conflicts by all five stakeholder groups are simultaneously considered. The results show farmer-herder conflicts are complex and preventing and /or resolving these conflicts require integrated approaches.
\end{abstract}

Keywords: farmer-herder, stakeholders, conflicts, triggers, agreement, Spearman rank correlation, Kendall coefficient of concordance, Ghana

\section{Introduction}

In West Africa, farmers and herders have coexisted for centuries. This coexistence has not been smooth, as it is often characterized by cooperation and conflicts (Moritz, 2010; Shettima \& Tar, 2008; Tonah, 2002; 2006). The development of interdependent relationships between farmers and herders has been facilitated through reciprocity and exchange in various forms (Moritz, 2010; Seddon \& Sumberg, 1997; Tonah, 2006). These symbiotic relationships have been instrumental in preventing and resolving conflicts that arose between farmers and herders in the past (Moritz, 2010; Pelican \& Dafinger, 2006). The increased frequency and spread of violent farmer-herder conflicts in many parts of sub-Saharan Africa suggest that these symbiotic relationships are either diminishing or losing their relevance in moderating conflicts between farmers and herders. In general, competition over land and water resources for survival among farmers and herders have increased over the years and thus farmer-herder conflicts assumed prominence over symbiotic or cooperative relationships (Seddon \& Sumberg, 1997). The concern among different stakeholders is not just that they are spreading but that the dimensions of violence have increased as well (Tonah, 2006).

In Ghana, as in many parts of West Africa, most of the violent farmer-herder conflicts involves Fulani (or Fulbe) herdsmen and settled farming communities. The Fulani are the most dominant pastoral group in West Africa (Abbass, 2014). The Fulani nomadic herders started migrating into Ghana in the early 1920s and 1930s from Niger, Burkina Faso and Mali and other areas in search of pasture, water and better economic prospects (Tonah, 2002). Today, the Fulani herdsmen are found in almost all agro-ecological zones of Ghana. As a result, violent conflicts between farming communities and Fulani herdsmen have become widespread. Increasingly, the spate of violent clashes and reprisal actions between farmers and Fulani herdsmen in many parts of Ghana has led to 
human deaths and displacement of people. While security agencies have intervened in many cases to prevent clashes, places such as Gushegu, Nangodi, Agogo, Dumso and various villages in Atebubu/ Amanteng and Pru districts in Ghana have recorded violent conflicts. For example, in February 2016, about 80 cattle belonging to Fulani herdsmen were killed by irate youth in Dumso in the Brong-Ahafo region in response to destruction of crops by cattle herded by Fulani herdsmen. Two farmers were also shot dead while in their farms by suspected Fulani herdsmen in Agogo in the Ashanti region. There has been a general dissatisfaction concerning the activities of Fulani herdsmen among the Ghanaian populace. In the media parlance, the situation is often described as the 'Fulani menace'.

These conflicts are curtailing the livelihood activities of farmers and herders. There is thus a need for sustainable solutions to these recurring conflicts. It will require that the triggers of these conflicts are understood to inform approaches to dealing with them. The important questions are: What are the triggers of farmer-herder conflicts? Do key stakeholder groups agree on the triggers of these conflicts? The purpose of this paper is therefore to identify the triggers (immediate causes) of farmer-herder conflicts from key stakeholders' perspectives and examine the level of agreement by the key stakeholders on the triggers of the conflicts. Fielmua, Boye Bandie and Ziemah (2014) undertook a similar study in the Upper West region of Ghana. However, while their paper focused on interaction among actors in pastoral practices, this paper focuses on stakeholder agreements on triggers of farmer-herder conflicts. The results of this study will provide a new insight into understanding the complexities of farmer-herder conflicts and may inform approaches to resolving or preventing them. For instance, if it is found that there is a concordance of perspectives among different stakeholders - that is, stakeholders are generally in agreement on what triggers farmer-herder conflicts - then identifying and implementing solutions to these conflicts is likely to be less complicated. Peaceful coexistence is essential for guaranteeing security and improvement in the lives, property and livelihoods of farmers and herdsmen.

\section{Related Literature on Farmer-Herder Conflicts}

In West Africa, farmer-herder conflicts are not only a common phenomenon over the years but also a common characteristic of their economic livelihood (Moritz, 2012; Tonah, 2006; Turner, Ayantunde, Patterson, \& Patterson III, 2011). In many places in sub-Saharan Africa, farmer-herder conflicts have escalated into widespread violence leading to property destruction, loss of human lives and displacement of people (Hussein, Sumberg, \& Seddon, 1999). At the center of farmer-herder conflicts is the issue of access to and use of land and water resources. The land and water resources are diminishing or increasing in scarcity due to several factors, causing intense competition and violent conflicts over their usage (Moritz, 2010; 2012; Oladele \& Oladele, 2011). As both herders and farmers livelihoods depend on their access to the same resources, any factor that increases competition over use of these resources also increases the possibility of conflicts between the two groups (Moritz, 2012). An important factor influencing resource availability for agricultural and pastoral production is climate change. Moritz (2012) states that although climate change is occurring everywhere, the Sahel region of Africa has been particularly volatile over the past decades. Climate change has brought about shrinking of environmental space and an increase in natural resource scarcity. This in turn results in increased competition and pressure on available resources and conflicts among the user groups (Abbass, 2014; Mwiturubani \& van Wyk, 2010; Okoli \& Atelhe, 2014). Climate change also causes conflicts as pastoralists migrate from areas characterized by drought and lack of feed into new areas in search of water and feed for their livestock. In sub-Saharan Africa, the southward migration of pastoral herds (Fulani herdsmen) into the humid and sub-humid zones is among the factors cited for the widespread and increasing farmer-herder conflicts (e.g. Fabusoro \& Oyegbami, 2009; Moritz, 2010; Tonah, 2006).

Population growth and expansion of agricultural production are also cited as driving forces of resource scarcity and violent conflicts. Rapid population growth increases competition over available resources (Adebayo, 1997; Mwiturubani \& van Wyk, 2010). Population growth has also caused a southward migration of many pastoralists from the Sudan-Sahelian zone as a means of avoiding conflicts but in the end create the potential for conflicts with farmers in the new areas (Moritz, 2012). Williams, Hiernaux and Fernández-Rivera (1999) indicate population growth has raised the demand for food leading to the expansion of farming into previously uncultivated areas used for livestock grazing. Commercial crop production results in encroachment on most of the traditional cattle routes, leaving pastoralists with insufficient passage for livestock to reach drinking points, causing conflicts (West African Network for Peacebuilding (WANEP), 2010). Expansion in agricultural production into formerly grazing areas and cattle routes increases the proximity of grazing livestock to cropped fields (Turner et al., 2011), resulting in livestock-induced crop damages. Livestock-induced crop damage, either on the field or in storage on farms, has been found to be the most important trigger of farmer-herder conflicts in most parts of West Africa (Abubakari \& Longi, 2014; Ofem \& Inyang, 2014; Ofuoku \& Isife, 2009; Tonah, 2002; 
2006; Turner, Ayantunde, Patterson, \& Patterson, 2007). Sometimes crop destruction is due to carelessness and indiscipline on the part of herdsmen through leaving livestock unattended or an intentional act as found by Tonah (2002) in the Volta plains of Ghana. Tonah (2002) found Fulani herdsmen would normally allow cattle to wander along the entire plain ostensibly in search of pasture and water but with the motive of preventing farming along the plain so that the land is available exclusively for their use. There is evidence that farmer-herder conflicts can occur in the mist of resource abundance and low animal and human population densities. This was observed in Ghana by Tonah $(2002 ; 2006)$ and in Cote d'Ivoire and Central Cameroon by Basset (1988). For instance, Tonah $(2002 ; 2006)$ found conflict to arise over access to the best agricultural lands and water sources between farmers and herders.

Cultural, religious and ethnic differences between herding and farming groups also cause conflicts by creating misunderstandings, suspicion, hostility and prejudices (Ahmadu, 2011; Moritz, 2012). In most parts of West Africa, the herdsmen (Fulani herdsmen) are considered strangers ('aliens') and the abuse of the host-stranger relationships has led to heightened conflicts, especially when herders start demanding equal rights of tenure and exploitation (Seddon \& Sumberg, 1997). Moreover, the fundamental rejection of herders' activities in some communities has been cited as causing conflicts in farmer-herder relationships (Yembilah \& Grant, 2014). Some farmer-herder conflicts experienced in recent times have been attributed to the inability of traditional (local) and government institutions to deal with them (Mortiz; 2010; Mwamfupe, 2015; Tonah, 2002). Hussein et al (1999) emphasized the breakdown of traditional mechanisms governing resource management and conflict resolution as one of the reasons for the increasing and violent farmer-herder conflicts. Moreover, international and local government policies on agricultural production, land tenure/land use and climate change contributes to farmer-herder conflicts (Ahmadu, 2011; Moritz, 2012; Mwamfupe, 2015). As to which group benefits or loses depends on the nature of the policies, but largely such policies are indicated to favor farmers. Policies aimed at fighting land degradation or favoring commercial agricultural production limit grazing movement and access to land and water resources for herders (Tonah, 2006). Other factors that have been cited as causes of farmer-herder conflicts are herdsmen engagement in social vices, such as cattle rustling, theft, highway robbery, female harassment and rape (e.g. Abubakari \& Longi, 2014; Ahmadu, 2011; Ofuoku \& Isife, 2009; Tonah, 2000), pollution of drinking water sources by livestock (Ofuoku \& Isife, 2009; Tonah, 2003), zero grazing land (Ofuoku \& Isife, 2009), herders' aggressive behaviors (Abubakari \& Longi, 2014; Ahmadu, 2011), disregard for local traditional authorities (Ahmadu, 2011), harassment of nomads by host communities, indiscriminate bush burning, inadequate grazing reserves and stock routes(ibid), changes or insecurity of land tenure and corrupt practices (Ahmadu, 2011; Mwamfupe, 2015), politics (Ahmadu 2011; Tonah 2000) and declining interdependent relationship between farmers and herders (Tonah 2000, 2006).

In examining the factors that cause farmer-herder conflicts, it is important to distinguish between the remote (long term) causes and triggers (immediate causes). Turner et al (2011) indicate resource related conflicts do not simply arise from increased competitive pressure driven by physical scarcity of a resource but that triggering events are often involved. Factors such as climate change, population increase, and expansion in agricultural production, social-cultural and religious differences, and changes in policies are generally considered remote causes of farmer-herder conflicts. The triggers of conflicts include destruction of crops, pollution of water bodies, engagement in social vices and inability of institutions (local and national) to deal with grievances. This study is focused on the triggers of farmer-header conflicts from the perspectives of different key stakeholder groups in the Upper West Region of Ghana.

\section{Materials}

The data used for this study were collected during a workshop entitled 'transhumance pastoralism and water use conflicts', which was organized by Global Water Initiative in 2012 in Wa, the Upper West regional capital of Ghana. The workshop brought together key stakeholders across the region in the wake of increasing conflicts between Fulani herdsmen and local farming communities in the region and Ghana as a whole. The workshop was organized to educate and facilitate a dispassionate stakeholder engagement geared at promoting peaceful coexistence between pastoralists and farming communities. The stakeholders invited to participate in the workshop were drawn from the following five categories: chiefs, landowners ('Tendamba') and traditional rulers, Fulani herdsmen and local cattle owners, crop farmers, civic society and media, and government agencies (Ministry of Food and Agriculture, Ghana Immigration Service/Ministry of Foreign Affairs, and district assemblies). In terms of distribution, there were 16 stakeholders from the chiefs and traditional rulers' group, 5 from the Fulani herdsmen and local cattle owners' group, 11 from the crop farmers' group, 6 from the civic society and media group, and 13 from the government agencies group. These numbers do not include the organizers, presenters and facilitators at the workshop. Two of the authors of this paper (first and last author) 
who facilitated the workshop collected the data.

During the first day of the workshop, there was a plenary session on causes of conflicts between Fulani herdsmen and farmers. The question raised for the participating stakeholders to answer was: what is at the center of conflicts between Fulani herdsmen and farmers? At the end of the session, 14 triggers of conflicts were identified by the stakeholders. They are (1) destruction of crops by cattle, (2) Fulani herdsmen engaging in social vices, (3) local benefactors shielding Fulani herders and their crimes, (4) farming close to water sources, (5) farming on cattle routes, (6) competing uses of water, (7) lack of systems to deal with grievances, (8) water pollution by cattle, (9) ineffective local water governance laws, (10) free-rider problem in water usage, (11) discrimination against Fulani herdsmen, (12) disregard for property rights of land and water, (13) false accusations against Fulani herdsmen, and (14) Fulani herdsmen bringing in diseased animals. Some of the triggers appear interlinked and thus no assumption of mutual exclusivity is made. An instrument was prepared containing the 14 triggers of conflicts identified by the stakeholders. In the second day of the workshop during focus group discussion session, the instrument was given to each stakeholder group (focus group) to discuss the triggers of conflicts and rank them in order of importance in triggering conflicts with 1 being the most important trigger in that order. This information serves as basis for the rest of this paper. Additionally, data on the socio-demographic characteristics of the stakeholders were collected at the end of the workshop and the descriptive statistics are presented in Table 1.

Table 1. Socio-Demographic Characteristics of Stakeholders

\begin{tabular}{lll}
\hline Age & & \\
\hline Minimum & 21 & \\
Maximum & 90 & \\
Mean & 47.51 & \\
Std Deviation & 18.45 & \\
N & 40 & Percent \\
Gender & Frequency & 93.0 \\
\hline Male & 40 & 7.0 \\
Female & 3 & 100 \\
N & 43 & \\
Educational Status & & 60.5 \\
Formal & 26 & 39.5 \\
No Formal & 17 & 100 \\
N & 43 & \\
Ethnicity & & 70.3 \\
\hline Dagaaba & 26 & 2.7 \\
Waala & 1 & 10.8 \\
Fulani & 4 & 8.1 \\
Akan & 3 & 2.7 \\
Dagomba & 1 & 2.7 \\
Ewe & 1 & 2.7 \\
Guan & 1 & 100 \\
N & 37 & 63.4 \\
Religion & & 22.0 \\
\hline Christian & 26 & 12.2 \\
Muslim & 9 & 2.4 \\
Animist & 5 & 100 \\
Atheist & 1 & \\
N & 41 & \\
\hline
\end{tabular}

*Only 43 completed the questionnaire on bio-data. $\mathrm{N}<43$ shows non-responses.

\section{Area Description}

The study area, Upper West Region, is located in northwestern part of Ghana covering a land area of about 18 thousand square kilometers. The region is bordered to the north by Burkina Faso and thus serves as key entry point by Fulani herdsmen and their cattle from the Sahel into Ghana. The indigenous inhabitants are distributed across three major ethnic groups: Dagaaba, Sissala and Wala. A majority of the population in the region is 
engaged in agriculture and related activities. The region is located in the guinea savanna zone and the vegetation is covered by grassland and drought resistant trees, such as shea, dawadawa and baobab. The region experiences a short monomial rainfall season (about 5 months) and long period of dry season. Though the region is suitable for cereal crops and livestock rearing, the long dry season tend to constrain agricultural production. The region is among the poorest in Ghana (Government of Ghana, undated) ${ }^{1}$.

\section{Method of Analysis}

Because the data are qualitative and can be ranked, we use non-parametric statistical techniques in the analysis. In determining the level of agreement between any two pair of stakeholder groups on the ranking of triggers of conflicts, we use the Spearman rank correlation method. This method is appropriate for assessing the level of agreement between two independent variables (or ratings). It does not depend on the distribution of the data and it is well suited for small sample sizes (Gauthier, 2001). The Spearman rank correlation coefficient, $r_{s}$ is given by

$$
r_{s}=1-\frac{6 \sum_{i=1}^{n} d_{i}^{2}}{n\left(n^{2}-1\right)}, \quad-1 \leq r_{s} \leq 1
$$

Where $d_{i}$ is difference between paired ranks (thus for each $x_{i}$ and $y_{i}$ data pair) and $n$ is the number of data pairs. The above equation is used as there are no tied ranks in the data (see Siegel \& Castellan, 1988; Gauthier, 2001). Given that there are 5 stakeholder groups ranking 14 triggers of farmer-herder conflicts, the following hypothesis (null) is tested between individual groups using the Spearman rank correlation method:

H1 There is no agreement between individual groups on the triggers of farmer-herder conflicts.

To examine the level of concordance among all stakeholder groups on the triggers of farmer-herder conflicts, we also employ Kendall's Coefficient of Concordance (Kendall's W). The Kendall's W takes values from zero (0) to one (1), where 0 represent no agreement (concordance) at all among the stakeholder groups and 1 represents perfect agreement. In this study, there are 5 stakeholder groups (designated as $m$ raters) rating 14 triggers of farmer-herder conflicts (designated as $n$ cases) in order of importance from 1 to 14 . Let the rating stakeholder group $i$ give trigger of farmer-herder conflict $j$ be $r_{i j}$ such that for each trigger of farmer-herder conflict, the row sum of ranks $\left(R_{i}\right)$ is equal to $\sum_{i=1}^{m} r_{i j}$. The squared deviation, $S$, is given by

$$
S=\sum_{j=1}^{n}\left(R_{i}-\bar{R}\right)^{2}
$$

Where $\bar{R}$ is the mean of the $R_{i}$ values. The Kendall's $W$ is then computed as

$$
W=\frac{12 s}{m^{2}\left(n^{2}-n\right)-m^{T}}, \quad 0 \leq W \leq 1
$$

$T$ is a factor to correct for tied ranks. If there are no tied ranks as in this paper, the Kendall's $W$ is simply

$$
W=\frac{12 s}{m^{2}\left(n^{2}-n\right)}, 0 \leq W \leq 1
$$

(Legendre, 2005; Siegel \& Castellan, 1988). The hypothesis (null) tested with the Kendall's W statistic is as follows:

H2 There is no concordance among all five stakeholder groups on the triggers of farmer-herder conflicts.

\section{Results and Discussion}

\subsection{Triggers of Farmer-Herder Conflicts}

The triggers of conflicts between herders and farmers are presented in Table 2 and Table 3. Table 2 presents the sum of ranks and average rank for each trigger of conflict, while Table 3 presents the top five triggers of conflicts ranked by each stakeholder group. Per the ranking criteria, the triggers of conflicts receiving lower sum of ranks/average rank are more important. From Table 2, destruction of crops by livestock is the most important trigger of conflicts, consistent with findings by studies (e.g. Abubakari \& Longi, 2014; Ofem \& Inyang, 2014; Tonah, 2002). It is asserted that the herdsmen leave cattle unattended and they enter farms and destroy crops by eating them up or trampling on them or both. Fulani herdsmen are said to intentionally drive their cattle into farms to feed on crops, with most of the incidence occurring in the night when farmers are absent from their farms. The study area experiences a single cropping season in a year and loss of crops expose farming

\footnotetext{
${ }^{1}$ More can be found at http://www.ghana.gov.gh/index.php/about-ghana/regions/upper-west
} 
households to precarious living for the rest of the year.

Some Fulani herdsmen are reportedly engaged in social vices of rape, theft of farm produce and cattle, cutting down of economic trees and highway armed robberies. There have been reported cases of women raped by herdsmen when they go to their farms or visit the wild to fetch firewood, burn charcoal or pick wild fruits. Bajin Pobia, cited in Forson-Asimenu (2011) reported that 'the social and economic activities of almost all communities in the Upper West Region have been curtailed by Fulani nomads: going to the bush to fetch sheanuts, baobab or dawadawa for home consumption is now dreaded by the women least they end up being raped; yam, cassava and millet that are left in farm houses are broken into by the Fulani herdsmen for their animals to feed on; economic trees such as shea trees are being slashed for fodder; water sources are drying up; and even ant hills are being converted to cattle feed when the Fulani herdsmen pour salted water on them'. Abubakari and Longi (2014) reported out of eleven highway robbery cases recorded between December 2011 and June 2014 in their study area, seven of the robberies were performed by Fulani herdsmen. Local benefactors of Fulani herdsmen activities are indicated to contribute to the conflicts. The groups that have been accused are local cattle owners and chiefs-traditional rulers. The local cattle owners engage the services of Fulani herdsmen and in return, the Fulani herdsmen receive material rewards and protection. Also, some chiefs and traditional rulers receive gifts (cattle) from Fulani herdsmen in order to settle on their land and be protected. As such, when destructive activities of the herdsmen are reported, the chiefs/traditional rulers are indicated to be less proactive in resolving them. Generally, systems whether formal or informal to deal with grievances emanating from farmer-herder interactions are indicated to be lacking. This may explain why some local communities have resorted to reprisal actions against Fulani herdsmen for destruction of farms, theft and rape. This is similar to what Tonah $(2002 ; 2006)$ found in Brong-Ahafo and Volta regions of Ghana.

Farming close to water bodies and on cattle routes are important triggers of conflicts in the area. When farmers cultivate crops close to water bodies or cattle routes, it makes it difficult to prevent cattle from straying into farms and grazing or trampling on crops en route to water bodies or to the wild. The herders indicate that the cattle have routes that they pass and lack of understanding and recognition of these routes by farmers create conflicts. In Nigeria, Adisa and Adekunle (2010) also found lack of awareness of stock routes/grazing reserves by farmers and herders as potential source of conflict. Regarding water sources and usage, competing uses of water and water pollution by cattle are important triggers of conflicts. Competing uses over water sources in addition to the inadequacy of water resources often generate conflict among the users, especially when it comes to sharing drinking water sources with animals. When cattle enter the water bodies to drink, they drop fecal matter which makes the water unwholesome for domestic use. In addition, the cattle muddy the water especially in the dry season where the water levels are very low. The area is already experiencing the effects of climate change as the rainfall pattern has changed, contributing to drying up of water bodies. Ofem and Inyang (2014) also found contamination of water sources by cattle as a major cause of conflict in parts of Nigeria.

The Fulani herdsmen are seen as free riders, since they use these water resources without contributing to their construction and/ or maintenance. Thus, there is the belief that the water resources are provided exclusively by government or non-governmental organizations (NGOs). This makes the communities who have contributed land, labor, and cash and in other ways to these water resources harbor indignation towards the Fulani herdsmen. In addition, laws governing or regulating water usage including local by-laws are not effectively enforced hence the use and/or misuse of the water resources often result in conflicts. Disregard for property rights, discrimination against Fulani herdsmen by the indigenous populations, false accusation by local communities against Fulani herdsmen for purported crimes and Fulani herdsmen bringing diseased animals to local communities are among the least important causes of conflict judging by the sum of ranks/average ranks. 
Table 2. Triggers of Farmer-Herder Conflicts

\begin{tabular}{lll}
\hline Trigger of Conflict & Sum of Ranks & Mean Rank \\
\hline Destruction of crops by cattle & 7 & 1.4 \\
Fulani herdsmen engaging in social vices & 22 & 4.4 \\
Local benefactors shielding Fulani herders' activities & 24 & 4.8 \\
Farming close to water bodies & 25 & 5.0 \\
Farming on cattle routes & 28 & 5.6 \\
Competing uses of water bodies & 35 & 7.0 \\
Lack of systems to deal with grievances & 35 & 7.0 \\
Water pollution by cattle & 38 & 7.6 \\
Ineffective local water governance laws & 42 & 8.4 \\
Free-rider problem in water usage & 49 & 9.8 \\
Discrimination against Fulani herdsmen & 52 & 10.4 \\
Disregard for property rights of land and water & 53 & 10.6 \\
False accusations against Fulani herdsmen & 57 & 11.4 \\
Fulani herdsmen bringing in diseased animals & 58 & 11.6 \\
\hline
\end{tabular}

Table 3. Top Five Triggers of Conflicts Ranked by Stakeholder Groups

\begin{tabular}{|c|c|c|c|c|c|}
\hline & & & Stakeholder groups & & \\
\hline Rank & Crop farmers & Civic Society- media & $\begin{array}{l}\text { Herdsmen-cattle } \\
\text { owners }\end{array}$ & Chiefs-traditional rulers & Government agencies \\
\hline 1 & $\begin{array}{l}\text { Fulani herdsmen } \\
\text { engaging in social } \\
\text { vices }\end{array}$ & $\begin{array}{l}\text { Destruction of crops } \\
\text { by cattle }\end{array}$ & $\begin{array}{l}\text { Competing uses of } \\
\text { water bodies }\end{array}$ & $\begin{array}{l}\text { Destruction of crops by } \\
\text { cattle }\end{array}$ & $\begin{array}{l}\text { Destruction of crops by } \\
\text { cattle }\end{array}$ \\
\hline 2 & $\begin{array}{l}\text { Destruction of crops } \\
\text { by cattle }\end{array}$ & $\begin{array}{l}\text { Farming close to water } \\
\text { bodies }\end{array}$ & $\begin{array}{l}\text { Destruction of crops } \\
\text { by cattle }\end{array}$ & $\begin{array}{l}\text { Fulani herdsmen engaging } \\
\text { in social vices }\end{array}$ & $\begin{array}{l}\text { Fulani herdsmen } \\
\text { engaging in social vices }\end{array}$ \\
\hline 3 & $\begin{array}{l}\text { Ineffective local water } \\
\text { governance laws }\end{array}$ & $\begin{array}{l}\text { Farming on cattle } \\
\text { routes }\end{array}$ & $\begin{array}{l}\text { Farming on cattle } \\
\text { routes }\end{array}$ & $\begin{array}{l}\text { Farming close to water } \\
\text { bodies }\end{array}$ & $\begin{array}{l}\text { Competing uses of } \\
\text { water bodies }\end{array}$ \\
\hline 4 & $\begin{array}{l}\text { Local benefactors } \\
\text { shielding } \\
\text { herders' activities }\end{array}$ & $\begin{array}{l}\text { Local benefactors } \\
\text { shielding } \\
\text { herders' activities }\end{array}$ & $\begin{array}{l}\text { Farming close to } \\
\text { water bodies }\end{array}$ & Farming on cattle routes & $\begin{array}{l}\text { Local benefactors } \\
\text { shielding } \\
\text { herders' activities }\end{array}$ \\
\hline 5 & $\begin{array}{l}\text { Disregard for property } \\
\text { rights of land and } \\
\text { water }\end{array}$ & $\begin{array}{l}\text { Fulani herdsmen } \\
\text { engaging in social } \\
\text { vices }\end{array}$ & $\begin{array}{l}\text { Pollution of water } \\
\text { by cattle }\end{array}$ & $\begin{array}{l}\text { Local benefactors shielding } \\
\text { Fulani herders' activities }\end{array}$ & $\begin{array}{l}\text { Pollution of water by } \\
\text { cattle }\end{array}$ \\
\hline
\end{tabular}

\subsection{Agreements on Triggers of Farmer-Herder Conflicts}

The ranking of triggers of farmer-herder conflicts by the five stakeholder groups are analyzed to determine agreements, if any, between individual stakeholder groups. The results of the Spearman rank correlation analysis are presented in Table 4. The correlation of ranking of triggers of conflicts between government agencies group and chiefs-traditional rulers' group is significant at the five percent level and that of government agencies group and crop farmers' group is significant at the ten percent level. There is no significant agreement between government agencies, Fulani herdsmen-cattle owners and civic society-media groups on the triggers of conflicts. Between chiefs-traditional rulers and civic society-media groups, the correlation of ranking of triggers of conflicts is significantly different from zero at the one percent level, and the correlation coefficient of $71 \%$ indicates high level of agreement on triggers of farmer-herder conflicts. Also, the agreement on the ranking of triggers of conflicts between chiefs-traditional rulers and crop farmers' groups is significant at the five percent level and the level of agreement $(60 \%)$ is high. The insignificant agreement between chiefs-traditional rulers and Fulani herdsmen-cattle owners on the ranking of triggers of conflicts point to the contrary as the chiefs-traditional rulers are often suspected as being in league with Fulani herdsmen due to their perceived reluctance to deal with reported cases of destructive activities of the latter. They are accused of receiving gifts (mostly cattle) from the herdsmen and thus tend to conceal or ignore their destructive activities (Tonah, 2002; 2006). Given that the farmers accusations have basis and also against the background that there is no significant concordance between chiefs-traditional rulers and Fulani herdsmen-cattle owners, a possible explanation may be that the chiefs-traditional rulers are aware of the core issues involved in the conflicts but are simply not 
responsive. The unresponsiveness may also be as a result of limited capacities for enforcement by the chiefs-traditional rulers.

The results further show that except with the chiefs-traditional rulers' group, there is no significant agreement between civic society-media group and any other stakeholder group on the ranking of triggers of conflicts. They side neither with crop farmers' group nor with Fulani herdsmen-cattle owners' group on the ranking of triggers of conflicts. This may reflect the neutrality that civic society and the media seek to project in their development work. The agreements on ranking of triggers of conflicts between Fulani herdsmen-cattle owners group and any of the other stakeholder groups are not significantly different from zero. This implies the Fulani herdsmen-cattle owners' group do not share any view with any other stakeholder group on the ranking of triggers of conflicts and vice versa. It can further be seen from Table 4 that the correlation coefficient between crop farmers and Fulani herdsmen-cattle owners groups on the ranking of triggers of conflicts is negative $(-0.064)$ though insignificant. However, it reflects the mutual accusations and counter-accusations between crop farmers and Fulani herdsmen-cattle owners in the area. Farmers often accuse Fulani herdsmen of crop destruction, pollution of water sources, crimes of theft and rape whilst Fulani herdsmen accuse farmers of farming on cattle routes, discrimination and false labeling. Similar results were obtained by Ofuoku and Isife (2010). Ofuoku and Isife (2009) found significant difference in farmers' and nomads' perception of the triggers of farmer-herder conflicts; among other factors, they indicated exaggeration of facts and denial of faults by both parties in conflict situations account for the difference. In general, the null hypothesis that there is no agreement between individual stakeholder groups on triggers of farmer-herder conflicts is rejected. The results show that there is some level of agreement on the ranking of triggers of conflicts between some stakeholder groups.

Table 4. Agreement on Ranking of Triggers of Farmer-Herder Conflicts

\begin{tabular}{|c|c|c|c|c|c|}
\hline & $\begin{array}{l}\text { Government } \\
\text { agencies }\end{array}$ & $\begin{array}{l}\text { Chiefs- } \\
\text { traditional rulers }\end{array}$ & $\begin{array}{l}\text { Civil society- } \\
\text { media }\end{array}$ & $\begin{array}{l}\text { Herdsmen-cattle } \\
\text { owners }\end{array}$ & $\begin{array}{l}\text { Crop } \\
\text { farmers }\end{array}$ \\
\hline $\begin{array}{l}\text { Government } \\
\text { agencies }\end{array}$ & 1.00 & & & & \\
\hline $\begin{array}{l}\text { Chiefs-traditional } \\
\text { rulers }\end{array}$ & $.569 * *$ & 1.00 & & & \\
\hline Civic society-media & .310 & $.710 * * *$ & 1.00 & & \\
\hline $\begin{array}{l}\text { Herdsmen-cattle } \\
\text { owners }\end{array}$ & .376 & .455 & .332 & 1.00 & \\
\hline Crop farmers & $.473 *$ & $.604 * *$ & .371 & -.064 & 1.00 \\
\hline
\end{tabular}

We employed the Kendall Coefficient of Concordance (Kendall's W) to test the level of agreement on the ranking of triggers of farmer-herder conflicts among all the five stakeholder groups simultaneously. As shown in Table 5, the Kendall's W statistic of 0.53 (53\%) indicates that there is moderate level of concordance among all stakeholder groups on the ranking of triggers of conflicts. The hypothesis that there is no concordance among all five stakeholder groups on the ranking of triggers of farmer-herder conflicts is therefore rejected. However, with Kendall's $\mathrm{W}$ of 0.53 , the level of concordance is far from being perfect. Thus, to some degree, differences exist in perceptions, understanding, experiences and interests on the importance attached to the triggers of farmer-herder conflicts among the stakeholder groups. Bell (2000) indicates that conflict resolution will be attainable only when there is substantial concordance about the causes of the conflict.

Table 5. Kendall's W Test of Concordance on Triggers of Conflicts

\begin{tabular}{ll}
\hline $\mathrm{N}$ & 5 \\
Kendall's W & .530 \\
Chi-Square & 34.463 \\
Df & 13 \\
Asymptotic Significance & .001 \\
\hline
\end{tabular}




\subsection{Implications of Farmer-Herder Conflicts for Livelihood Security}

Inattention to farmer-herder conflicts will have both short- and long-term consequences for the livelihood of many people and also for the environment that support agricultural and pastoral production. As Moritz (2010) points out, farmer-herder conflicts not only have a direct impact on farmers-herders lives and livelihoods but also disrupt and threaten the sustainability of agricultural and pastoral production. These conflicts can lead to a decline in agricultural production and productivity in general and food production in particular, thereby worsening food security situation of farming and non-farming households. Livelihood activities of farming and herding households are already being curtailed by these conflicts in the study area. Farmers dreading to go to their farms for fear of being attacked prevent them from undertaking farming activities such as planting, weeding and harvesting at important times. When farmers' crops are destroyed by cattle, they lose their investment and are exposed to livelihood insecurity. The study area experiences a single agricultural season, meaning only one harvest is expected to sustain these households for an entire year. Among the rural women, sheanut and dawadawa picking in the farms and wild are among the major economic activities they engage in. The income raised from these activities play an important role in supplementing low farm incomes, especially during the off-agricultural season. Because of frequent and rising farmer-herder conflicts, these income generating and livelihood support activities are being curtailed. Women dread to go and pick or harvest these fruits for fear of being attacked and raped. Furthermore, the cutting down of economic trees for cattle to feed on have serious repercussions for the livelihood of rural women and the environment. For the herders, violent conflicts leading to killing of cattle, seizure of cattle or restrictions on access to key resource areas will endanger their livelihood. Driving herders into marginal areas will lower cattle and milk production and productivity. Prevention and resolution of farmer-herder conflicts is therefore essential for sustainable livelihood of farmers and herders and indirectly for all those whose livelihoods are linked to farming and pastoral production.

\section{Conclusion and Suggestions for Future Research}

In this paper, we identify triggers of farmer-herder conflicts and the extent of agreement among stakeholder groups on these triggers. Fourteen triggers of conflicts are identified. The destruction of crops in storage and on the field by cattle is the key trigger of farmer-herder conflicts, consistent with other studies in Ghana and elsewhere in the West African sub-region. The level of agreement between stakeholder groups on the importance attached to the triggers of conflicts is generally weak, however. Indeed, the level of concordance among all the five stakeholders on the importance attached to the triggers of conflicts is moderate though asymptotically significant. This suggests that bottlenecks may arise in reaching agreed solutions to farmer-herder conflicts among stakeholder groups involved and the awareness of this should inform approaches to dealing with these conflicts. Proper stakeholder engagement among other measures is crucial to resolving existing farmer-herder conflicts and/or preventing future ones. Dealing effectively with farmer-herder conflicts will require the opinions, efforts and cooperation of all the stakeholders involved. Furthermore, it will require that policy measures and actions be centered on the triggers of farmer-herder conflicts identified.

The limitation in this paper is in relation to the data collection procedure as well as depth of data. The data were collected during a workshop that brought together key stakeholders who are leaders of farmers and herders or are involved with farmers and herders. While this is characterized as convenience sampling, it helped in meeting and interacting with key stakeholders from the affected districts as well government and civic society institutions in the region through which the data were collected. Additionally, since it was a workshop session, there was not enough time to collect data beyond what is presented in this paper. The stakeholders' workshop itself suggests a possible path for the identification of solutions to these types of conflicts. Research suggests that the voice of stakeholders, especially those who are marginalized, can be enhanced through efforts of bringing stakeholders together for workshops and other means of fostering two-way communication (see, for instance, Valdivia, Danda, Sheikh, James Jr, Gathaara, Mbure, Murithi, \& Folk, 2014). Thus, the fact that stakeholders met and discussed farmer-herder conflicts and their sources suggests a possible means of identifying or working toward agreement and resolutions. Further research is needed to assess the extent to which such interactions help build bridges under these circumstances and with respect to these types of conflicts.

\section{Acknowledgement}

The researchers wish to acknowledge Global Water Initiative and its partners (CARE International, Catholic Relief Services (CRS), International Union for the Conservation of Nature (IUCN) and PRONET-North) for providing the platform and cooperation in collecting the data used in this paper. 


\section{References}

Abbass, M. I. (2014). No retreat no surrender conflict for survival between Fulani pastoralists and farmers in Northern Nigeria. European Scientific Journal, 8(1), 331-346.

Abubakari, A., \& Longi, F. Y. T. (2014). Pastoralism and violence in northern Ghana: socialization and professional requirement. International Journal of Research in Social Sciences, 4(5), 102-111.

Adebayo, A. G. (1997). Contemporary dimensions of migration among historically migrant Nigerians. Journal of Asian and African Studies, 32(1-2), 93-109. https://doi.org/10.1177/002190969703200108

Adisa, R. S., \& Adekunle, O. A. (2010). Farmer-herdsmen conflicts: A factor analysis of socio-economic conflict variables among arable crop farmers in North Central Nigeria. Journal of Human Ecology, 30(1), 1-9.

Ahmadu, H. J. (2011). Farmer-Herder Conflict: Exploring the Causes and Management Approaches in the Lake Chad Region Nigeria (Unpublished PhD dissertation), Universiti Utara Malaysia.

Bassett, T. J. (1988). The political ecology of peasant - herder conflicts in the Northern Ivory Coast. Annals of the Association of American Geographers, 78(3), 453-472.

https://doi.org/10.1111/j.1467-8306.1988.tb00218.x

Bell, C. (2000). Peace Agreements and Human Rights, Oxford University Press, Oxford.

Dosu, A. (2011). Fulani-farmer conflict and climate change in Ghana: migrant Fulani herdsmen clashing with Ghanaian farmers in struggles for diminishing land and water resources. ICE Case Studies 258. Retrieved from http://www1.american.edu/ted/ICE/fulani.html

Fabusoro, E., \& Oyegbami, A. (2009). Key issues in livelihoods security of migrant Fulani pastoralists: empirical evidence from Southwest Nigeria. Journal of Humanities, Social Sciences and Creative Arts, 4(2), 1-20.

Fielmua, N., Bandie, R. D. B., \& Ziemah, M. K. (2014). Managing Pastoralism and Water Rights in the Upper West Region of Ghana: A Blame Game among Actors. Journal of Sustainable Development, 7(1), 72-84. https://doi.org/10.5539/jsd.v7n1p72

Forson-Asimenu, K. (2011). Fixing the Fulani Puzzle. Retrieved from http://www.ghanaweb.com/GhanaHomePage/features/artikel.php?ID=222165

Haro, G. O., Doyo, G. J., \& McPeak, J. G. (2005). Linkages between community, environmental, and conflict management: experiences from Northern Kenya. World Development, 33(2), 285-299. https://doi.org/10.1016/j.worlddev.2004.07.014

Gautheir, T. D. (2001). Detecting trends using Spearman's rank correlation coefficient. Environmental forensics, 2(4), 359-362. https://doi.org/10.1080/713848278

Government of Ghana (undated). Retrieved from http://www.ghana.gov.gh/index.php/about-ghana/regions/upper-west.

Hussein, K., Sumberg, J., \& Seddon, D. (1999). Increasing violent conflict between herders and farmers in Africa: claims and evidence. Development Policy Review, 17(4), 397-418. https://doi.org/10.1111/1467-7679.00094

Legendre, P. (2005). Species associations: the Kendall coefficient of concordance revisited. Journal of Agricultural, Biological, and Environmental Statistics, 10(2), 226-245. https://doi.org/10.1198/108571105X46642

Moritz, M. (2010). Understanding herder-farmer conflicts in West Africa: outline of a processual approach. Human Organization, 69(2), 138-148. https://doi.org/10.17730/humo.69.2.aq85k02453w83363

Moritz, M. (2012). Farmer-herder conflicts in sub-Saharan Africa. Retrieved from http://www.eoearth.org/view/article/152734

Mwamfupe, D. (2015). Persistence of farmer-herder conflicts in Tanzania. International Journal of Scientific and Research Publications, 5(2), 1-8.

Mwiturubani, D. A., \& Van Wyk, J. A. (Eds), (2010). Climate Change and Natural Resources Conflicts in Africa. Institute for Security Studies, Monographs No.170. Retrieved from http://uir.unisa.ac.za/bitstream/handle/10500/13312/Climate\%20change\%202010.pdf?sequence=1

Ofem, O. O., \& Inyang, B. (2014). Livelihood and conflict dimension among crop farmers and Fulani herdsmen in Yakurr region of Cross River State. Mediterranean Journal of Social Sciences, 5(8), 512-519.

Ofuoku, A. U., \& Isife, B. I. (2009). Causes, effects and resolution of farmers-nomadic cattle herders conflict in 
Delta state Nigeria. International Journal of Sociology and Anthropology, 1(2), 047-054.

Okoli, A. C., \& Atelhe, A. G. (2014). Nomads against natives: a political ecology of herder/farmer conflicts in Nasarawa state, Nigeria. American International Journal of Contemporary Research, 4(2), 76-88.

Oladele, T. O., \& Oladele, O. I. (2011). Effect of pastoralist-farmers conflict on access to resources in savanna area of Oyo State Nigeria. Life Sciences Journal, 8(2), 616-621.

Pelican, M., \& Dafinger, A. (2006). Sharing or dividing the land?: land rights and herder-farmer relations in a comparative perspective. Canadian Journal of African Studies, 40(1), 127-151.

Seddon, D., \& Sumberg, J. (1997). Conflict between farmers and herders in Africa: an analysis. Semi-Arid (Rangelands) Production System Project R6618, Livestock Production Program. Retrieved from.https://assets.publishing.service.gov.uk/media/57a08d5140f0b649740017b8/R6618a.pdf

Shettima, A. G., \& Tar, U. A. (2008). Farmer-pastoralist conflict in West Africa: exploring the causes and consequences. Information, Society and Justice Journal, 1(2), 163-184.

Siegel, S. C., \& Castellan, J N. (1988). Nonparametric statistics for the behavioral sciences. McGraw-Hill, New York.

Tonah, S. (2000). State policies, local prejudices and cattle rustling along the Ghana-Burkina Faso border. Africa, 70(4), 551-567. https://doi.org/10.3366/afr.2000.70.4.551

Tonah, S. (2001). Fulani pastoral migration, sedentary farmers and conflict in the middle belt of Ghana. Paper presented at the National Conference on Livelihood and Migration, ISSER, University of Ghana, Legon.

Tonah, S. (2002). Fulani pastoralists, indigenous farmers and the contest for land in Northern Ghana. Africa Spectrum, 37(1), 43-59.

Tonah S. (2003). Conflicts and Consensus between Migrant Fulani Herdsmen and Mamprusi Farmers in Northern Ghana. In Kroger, F., \& Meier, B. (Eds.), Ghana's North: research on culture, religion and politics of societies in transition, pp.79-100, Frankfurt/Main: Lang.

Tonah S. (2006). Migrations and farmer-herder conflicts in Ghana's Volta Basin. Canadian Journal of African Studies, 40(1), 152-178.

Turner, M., Ayantunde, A. A., Patterson, E. D., \& Patterson, K. P. (2007). Conflict management for improved livestock productivity and sustainable natural resource use in Niger. ILRI Report. Retrieved from https://cgspace.cgiar.org/bitstream/handle/10568/1304/ILRIProjectDoc.pdf?sequence=3\&isAllowed=y

Turner, M. D., Ayantunde, A. A., Patterson, K. P., \& Patterson III, E. D. (2011). Livelihood transitions and the changing nature of farmer-herder conflict in Sahelian West Africa. The Journal of Development Studies, 47(2), 183-206. https://doi.org/10.1080/00220381003599352

Valdivia, C., Danda, M. K., Sheikh, D., James, H. S., Gathaara, V., Mbure, G., Murithi, F., \& Folk, W. (2014). Using translational research to enhance farmers' voice: a case study of the potential introduction of GM cassava in Kenya's coast. Agriculture and Human Values, 31(4), 673-681. https://doi.org/10.1007/s10460-014-9536-0

West African Network for Peace Building (2010). Concept paper on agriculture and pastoralist conflicts in West Africa Sahel. Retrieved from http://www.wanep.org/wanep/attachments/article/158/cp_agric_pastoralist_aug2010.pdf

Williams, T. O., Hiernaux, P., \& Fernández-Rivera, S. (1999). Crop-livestock systems in sub-Saharan Africa: Determinants and intensification pathways. In McCarthy et al (Eds.), Property Rights, Risk, and Livestock Development, IFPR, Washington DC, 132-151.

Yembilah, R. \& Grant, M. (2014). The political ecology of territoriality: territorialities in farmer-herder 'relationships in Northern Ghana. GeoJournal, 79(3), 385-400. https://doi.org/10.1007/s10708-013-9509-7

\section{Copyrights}

Copyright for this article is retained by the author(s), with first publication rights granted to the journal.

This is an open-access article distributed under the terms and conditions of the Creative Commons Attribution license (http://creativecommons.org/licenses/by/3.0/). 